\title{
Sensitivity of lettuce cultivar Lucy Brown to pre-planting herbicide application
}

\author{
Nicole B da Riva ${ }^{1} \mathbb{D}$; Denis Fernando Biffe ${ }^{1} \mathbb{D}$; Daniel Nalin ${ }^{1} \mathbb{D}$; Rafael R Mendes ${ }^{1} \mathbb{D}$; Vanessa FV Silva ${ }^{1} \mathbb{D}$; \\ Luiz Augusto I Ferreira ${ }^{1} \mathbb{D} ;$ Jamil Constantin ${ }^{1} \mathbb{D}$
}

${ }^{1}$ Universidade Estadual de Maringá (UEM), Maringá-PR, Brasil; nihdariva@hotmail.com; denisbiffe@gmail.com; danielnalin97@gmail. com (author for correspondence); rafaromero.mendes@gmail.com; vfvitalsilva@gmail.com; luizinojosaf@gmail.com; jamil.constantin@ gmail.com

\begin{abstract}
Due to the low availability of herbicide active ingredients, the chemical weed management in lettuce crop is a challenge. The aim of this study was to evaluate the sensitivity of lettuce to the pre-planting application of the herbicides flumioxazin and trifluralin alone or in tank-mixture in lettuce, Lucy Brown cultivar. Two experiments were conducted. In experiment A, the soil was tilled before the herbicide application and it was tilled again before seedling transplanting. In experiment $\mathrm{B}$, the soil was tilled just once before the herbicide application. The experimental design was in randomized blocks in a factorial scheme $(3 \times 3)+1$ ( 2 factors with 3 levels and an additional control) with 4 replicates. We applied flumioxazin $\left(120 \mathrm{~g} \mathrm{ha}^{-1}\right)$, trifluralin $\left(450 \mathrm{~g} \mathrm{ha}^{-1}\right)$ and flumioxazin + trifluralin $\left(120+450 \mathrm{~g} \mathrm{ha}^{-}\right.$ $\left.{ }^{1}\right)$ in three different seasons before transplanting (0,7 and 14 days). Lettuce productivity after trifluralin application $\left(48.4 \mathrm{t} \mathrm{ha}^{-1}\right)$ was higher than after flumioxazin application $\left(16.8 \mathrm{t} \mathrm{ha}^{-1}\right)$ in experiment $\mathrm{A}$. In experiment $\mathrm{B}$, flumioxazin decreased the number of lettuce leaves (25.6) at 14 DAT; no differences in lettuce productivity were verified, though. The herbicide trifluralin caused lower levels of phytotoxicity and was the most selective between the treatments when applied in the three seasons in both experiments.
\end{abstract}

Keywords: Lactuca sativa, weed management, phytointoxication, flumioxazin, trifluralin, tank mix.

\section{RESUMO}

Sensibilidade da alface cultivar Lucy Brown à aplicação de herbicidas em pré-plantio

Devido à baixa disponibilidade de ingredientes ativos de herbicidas, o manejo químico de plantas daninhas na cultura da alface é um desafio. Objetivou-se avaliar a sensibilidade da alface à aplicação dos herbicidas flumioxazin e trifluralin, isolados ou em mistura em pré-plantio de mudas de alface cultivar Lucy Brown. Dois experimentos foram realizados. O experimento A recebeu uma operação de revolvimento no solo antes da aplicação dos herbicidas e outra antes do transplantio das mudas; o experimento B recebeu apenas um revolvimento do solo anterior à aplicação do herbicida. $\mathrm{O}$ delineamento experimental foi em blocos casualizados em esquema fatorial $(3 \times 3)+1$ ( 2 fatores com 3 níveis e uma testemunha adicional) com 4 repetições. Ambos experimentos receberam os tratamentos herbicidas flumioxazin (120 $\left.\mathrm{g} \mathrm{ha}^{-1}\right)$, trifluralin $\left(450 \mathrm{~g} \mathrm{ha}^{-1}\right)$ e a associação flumioxazin + trifluralin $\left(120+450 \mathrm{~g} \mathrm{ha}^{-1}\right)$ aplicados em três épocas distintas antecedendo o transplantio ( 0,7 e 14 dias). A produtividade de alface após aplicação de trifluralin $\left(48,4 \mathrm{t} \mathrm{ha}^{-}\right.$ $\left.{ }^{1}\right)$ foi maior do que sob aplicação de flumioxazin $\left(16,8 \mathrm{tha}^{-1}\right)$ no experimento A. No experimento B flumioxazin aos 14 DAT reduziu o número de folhas de alface $(25,6)$, todavia não houve diferenças de produtividade. $\mathrm{O}$ herbicida trifluralin causou menores níveis de fitointoxicação na alface e foi o mais seletivo dentre os tratamentos quando aplicado nas três épocas nos dois experimentos.

Palavras-chave: Lactuca sativa, manejo de plantas daninhas, fitointoxicação, flumioxazin, trifluralin, mistura em tanque.

\section{Received on November 25, 2020; accepted on June 23, 2021}

$\mathrm{L}$ ettuce (Lactuca sativa) is considered the most important leaf vegetable worldwide (Sala \& Costa, 2012). In national horticulture, lettuce stands out among the leafy vegetables as the most important for Brazilian diet, consumed most of times in salad, it means, in natura (Resende et al., 2007).

As in other agricultural activities, phytosanitary management plays a fundamental role for maintenance of productivity and quality of the harvested product. The occurrence of weeds on lettuce crop is related to productivity, such as competition for water, light, nutrients and release of allelopathic compounds. Besides causing productivity losses and decrease in the quality of the crop, weed affects the leaf firmness and, also nitrate and carotene content (Giannopolitis et al., 1989).

The vegetable production scenario in Brazil has been changing in the latest decades. The fierce competition in the market makes necessary the specialization in exploration and professionalization of the activity (Giordani et al., 2000). In this context, weed management in lettuce crop still 
depends on intensive labor, since only three active ingredients of herbicides are registered for the crop in Brazil, being two recommended for postemergence application in the total area and one recommended to be sprayed as a directed post-emergence application (Agrofit, 2021). No option for application in soil, at pre-planting, can be found.

Lack of options for chemical control of weeds on lettuce crop and a small number of recent scientific studies have motivated studies searching alternatives to chemical control, as well as selectivity of different application modes. Lettuce is very sensitive to residues of herbicides in soil; so, using herbicides in lettuce production fields requires a lot of care, especially considering pre-emergence application (Fennimore et al., 2011).

Herbicide selectivity can be considered a differential response among species or varieties (Monquero et al., 2011). In other words, a cropselective herbicide is one which causes the phytotoxic effect on target plants without harming the crop (Maciel et al., 2019; Bereta et al., 2021).

Trifluralin is an herbicide recommended for controlling grasses and some broadleaves in pre-emergence, however, for an efficient chemical management, it is recommended to incorporate it into the soil. Incorporation usually occurs after the application of the herbicide, in order to reduce losses caused by volatilization and photodegradation due to its high vapor pressure (Chowdhury et al., 2020). The experiments which evaluated selectivity of the herbicides metolachlor, oxadiazon, oxyfluorfen, pendimethalin, thiobencarb and trifluralin, applied on pre-transplanting of lettuce cultivar Elisa, considered selective trifluralin $\left(1.15 \mathrm{~kg} \mathrm{ha}^{-1}\right)$ and thiobencarb $(5.0 \mathrm{~kg}$ ha $^{-1}$ ) herbicides (Giordani et al., 2000).

Flumioxazin is a product of contact action, whose mechanism of action is based on the inhibition of the enzyme protoporphyrinogen oxidase (PROTOX), being able to be applied in pre and post-emergence in order to control broadleaf weeds (Tiburcio et al., 2012). Evaluating herbicide selectivity in cabbage crop, Reis et al. (2017) verified high percentage injury to crop at 15 and 30 days after flumioxazin application (40 $\left.\mathrm{g} \mathrm{ha}^{-1}\right)$, when the herbicide was applied one day before seedling transplanting. In a study carried out on head lettuce "sharpshooter", three application intervals were evaluated (90, 60 and 30 days) before sowing. The herbicides tested were flumioxazin ( 71 , 105 and $211 \mathrm{~g} \mathrm{ha}^{-1}$ ) and two formulations of oxyfluorfen, 280 and $560 \mathrm{~g} \mathrm{ha}^{-1}$, each. The results showed that flumioxazin (71 $\mathrm{g} \mathrm{ha}^{-1}$ ) was selective for lettuce crop in the three evaluated application intervals (Fennimore et al., 2011). Herbicide selectivity in crops can be influenced by cultivar, plant growth stage and climatic conditions (Oliveira Junior \& Inoue, 2011).

The lettuce cultivation in field under conventional system is the most important, considering area and production(Echer etal., 2016). Under this system, the seedbeds are prepared prior to planting, promoting incorporation of organic and chemical residues applied to the soil. In horticulture, an intense soil tickler (harrowing and seedbed raising operation) is common, mainly for crops, such as lettuce, in which seedbeds preparation is a common practice (Ferreira et al., 2009).

The authors in this study believe that lettuce cultivar Lucy Brown could be resistant to the application of trifluralin, flumioxazin and the mix of these two herbicides at pre-planting and in different types of soil management, which means, under tillage system or no-tillage. Given the above, this study aimed to evaluate the sensitivity of the lettuce cultivar Lucy Brown to the application of herbicides in pre-planting seedlings.

\section{MATERIAL AND METHODS}

The experiments were carried out in the vegetable-garden of Setor de Olericultura, at Universidade Estadual de Maringá, in Centro de Treinamento de Irrigação, municipality of MaringáPR $\left(23^{\circ} 25^{\prime} 00^{\prime} \mathrm{S}, 51^{\circ} 57^{\prime} 05^{\prime \prime} \mathrm{W}\right.$, altitude $542 \mathrm{~m})$. The soil in the experimental area had $\mathrm{pH}\left(\mathrm{H}_{2} \mathrm{O}\right)=7.1 ; \mathrm{C}=19.6 \mathrm{~g} \mathrm{dm}^{-3}$; $\mathrm{V}=83.71 \%, \mathrm{CTC}=22.30 \mathrm{cmol}_{\mathrm{c}} \mathrm{dm}^{-3}$; clay $=75.68 \%$; sand $=12.26 \%$ and silt $=12.06 \%$. Throughout the experiment, maximum, minimum and daily average temperatures were $37^{\circ} \mathrm{C}, 11^{\circ} \mathrm{C}$ and $24^{\circ} \mathrm{C}$ respectively, and the maximum and the minimum rainfall were $26 \mathrm{~mm}$ and 0.2 $\mathrm{mm}$, respectively.

The experimental design was in randomized blocks, in a $(3 \times 3)+1$ factorial scheme, with four replicates. The factors consisted of herbicide treatments in different application seasons. The treatments were flumioxazin $\left(120 \mathrm{~g} \mathrm{ha}^{-1}\right)$, trifluralin $\left(450 \mathrm{~g} \mathrm{ha}^{-1}\right)$ and flumioxazin + trifluralin $\left(120+450 \mathrm{~g} \mathrm{ha}^{-1}\right)$ in three different application seasons $(0,7$ and 14 days before the lettuce seedling transplanting) and an additional herbicide-free control.

The study was conducted in two experiments (A and $B$ ) with the same experimental design, with different soil preparation, though. In experiment A, two different soil tillage operations were performed: the first operation was performed before the herbicide application in each of the three seasons [0, 7 and 14 days before transplanting (DAT)] and the second operation was performed immediately before the lettuce seedling transplanting for all treatments. Therefore, the transplanting was performed on the same day for all treatments. In experiment B, just one soil tillage operation was performed, before the herbicide application in each season ( 0,7 and 14 DAT), no soil tillage operation immediately before transplanting was performed, though.

The plots consisted of a seedbed measuring $1.20 \times 2.70 \mathrm{~m}$, totalizing 3.24 $\mathrm{m}^{2}$, with four planting rows spaced 0.30 $\mathrm{m}$ between plants and $0.30 \mathrm{~m}$ between rows, using 36 plants in the total area. The authors considered as useful area for evaluations and harvesting, the fourteen central plants, not considering the borders. The seedbeds are historically used for planting of vegetables, presenting organic residues of previous crops. So, seedbeds were prepared with the aid of a micro-tractor with rotary tiller $(10 \mathrm{~cm})$ before applying the herbicides, which occurred from the fourteenth day before seedling transplanting (DAT). Top-dressing fertilizations were performed, using 
urea $(50 \% \mathrm{~N})\left(200 \mathrm{~kg} \mathrm{ha}^{-1}\right)$ and foliar fertilizer Yogen $2\left(28 \% \mathrm{~N} ; 10,0 \% \mathrm{P}_{2} \mathrm{O}_{5}\right.$; $1,0 \% \mathrm{Mg} ; 1,0 \% \mathrm{~S} ; 0,03 \% \mathrm{~B} ; 0,05 \%$ $\mathrm{Cu} ; 0,10 \% \mathrm{Mn} ; 0,02 \% \mathrm{Mo} ; 0,10 \% \mathrm{Zn}$ ) $\left(12 \mathrm{~kg} \mathrm{ha}^{-1}\right)$. The doses were splitted in five weekly applications, from the first week after seedling transplanting. Urea fertilizer was broadcast and Yogen 2 was diluted in water and manually watered.

The cultivar was chosen considering the market and climatic adaption to the region. Thus, in the two experiments, we used the head lettuce cultivar Lucy Brown, which presents an approximately 45-55-day cycle after transplanting. The plants are big and vigorous, showing thick leaves, being an excellent protection to the head, which is big, with good compactness and weight and light green coloration (Seminis Vegetable Seeds, 2016). The lettuce seeds were sown on trays with 100 cells using the commercial substrate Carolina Soil ${ }^{\circledR}$ and the seedlings were transplanted 25 days after sowing.

The herbicides were applied on 0,7 and 14 days after transplanting (DAT) the lettuce seedlings. When the herbicides were applied no weeds were found in the experimental area. For all applications, we used a $\mathrm{CO}_{2}$-based constant pressure backpack sprayer equipped with an application bar with four XR-110.02 fan-tips, $0.5 \mathrm{~m}$ apart, under pressure of $38 \mathrm{lb} \mathrm{in}^{-2}$, at an application rate of $200 \mathrm{~L} \mathrm{ha}^{-1}$.

Weeds were manually controlled during all experimental period, so the area was kept clean and free from weeds. Insecticides and fungicides were not applied during the experiment.

Irrigation was performed daily using two-nozzle sprinklers JET8020, spaced $12 \times 12 \mathrm{~m}, 30$ mca pressure, with 0.90 $\mathrm{m}^{3} \mathrm{~h}^{-1}$ flow rate, in three watering shifts, 15 minutes each. This management was chosen to prevent the plants from being in conditions of scarcity and excess water. The shifts were performed at 9 a.m., 12 a.m. and 3 p.m., totalizing 4.68 $\mathrm{mm}$ day $^{-1}$ irrigation depth.

Visual evaluations were done during the crop cycle. The authors noticed symptoms at 7,21 and 35 days after transplanting (DDT) on lettuce seedlings in the seedbeds. During the visual evaluations, we scored from 0 to $100 \%$ on the useful area of each plot, where zero refers to no visual damage in plants and 100 refers to death of plants, according to the note scale proposed by Frans (1972).

At harvesting time, we evaluated growth and production indicators: leaf area, number of leaves and fresh head mass (crop yield). In order to obtain the leaf area, a leaf area meter (Delta T. Devices $\left.{ }^{\circledR}\right)$ was used. The number of leaves was determined using two random samples of plants from each plot right after harvesting, excluding the senescent outer leaves. The counting was done highlighting the leaves considered usable for consumption and with a length greater than $3 \mathrm{~cm}$.

In order to evaluate the crop yield, eight plants of the useful area of each plot were harvested, cutting the stem close to the ground with the aid of a knife. After cleaning the dead and senescent leaves, the plants were weighed using a digital scale with a resolution to two decimal places.

Data were submitted to homogeneity of variance tests (Bartllet) and test of residual normality (Lilliefors), meeting the assumptions of the analysis of variance (Banzatto \& Kronka, 2015). Then, data were submitted to variance analysis and unfolding for significant interactions among factors. The average of treatments was compared using Tukey test at $5 \%$ probability and the control was compared to the treatments by Dunnet test at $5 \%$ probability, using GENES statistical software.

\section{RESULTS AND DISCUSSION}

\section{Experiment A}

Significant interaction between factors for all evaluated variables $(p<0.05)$ was verified. Herbicide injuries, when applied at 0,7 and 14 days before lettuce seedling transplanting, showed a decrease in note scale in relation to phytointoxication, since the plants showed a tendency to recover during the evaluation.

In the first evaluation, performed 7 days after transplanting (DDT), trifluralin applied isolated provided the

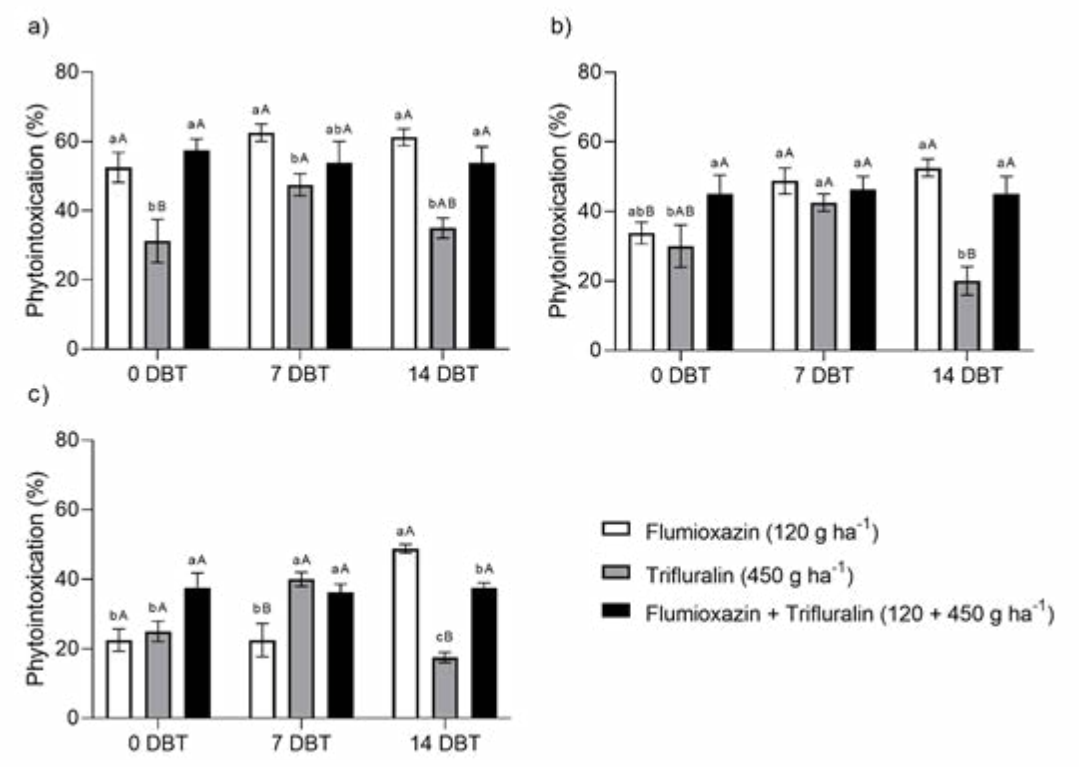

Figure 1. Phytointoxication evaluation of lettuce plants cv. Lucy Brown at 7 (a), 21 (b) and 35 (c) days after transplanting (DDP) in the experiment A (treatments consisted of different herbicide application seasons prior to planting (15, 7 and 0 DAT) and two soil tillage operations, one performed before herbicide treatments and one immediately prior to planting the lettuce seedlings); DBT= days before transplanting. Same lowercase letters do not differ between the herbicide treatments at the same application season and, same uppercase letters do not differ between the herbicide treatments between application seasons; Tukey test, $5 \%$ probability. Maringá, UEM, 2016. 
lowest phytotoxicity value in the scale in all application seasons. However, in the last evaluation (35 DDT), the herbicide trifluralin, applied isolated at 7 DAT, showed higher phytotoxicity when compared with flumioxazin application in isolated form, not influencing yield losses, since phytointoxication averages were reduced until the end of the cycle. Chaudhari et al. (2015) also observed the recovery of the tomato crop after high phytotoxicity levels caused by trifluralin (560 and $840 \mathrm{~g} \mathrm{ha}^{-1}$ ), preplanting incorporated, early in the development cycle. Studying lettuce cv. Elisa, Giordani et al. (2000) observed the same symptoms when applying trifluralin pre-planting incorporated three days before seedling transplanting. The herbicide trifluralin was considered selective, due to a possible recovery of the crop. In the first application season (0 DAT), a greater recovery of lettuce plants was noticed, it means, a marked phytotoxicity reduction was verified, when compared to the other seasons (7 and 14 DAT) during the evaluations (7, 21 and 35 DDT). Such symptoms presented as a slight necrosis in the basal leaves.

The hypothesis which best explains the results found refers to the soil tillage performed before transplanting. The treatments corresponding to herbicide application at 7 and 14 DAT were incorporated to soil after tillage on the seedling planting date, it means, after one and two weeks, respectively.
Due to the use of irrigation in the experimental area, high humidity may have contributed to a small incorporation of the product in the first soil layers. Trifluralin shows a better performance in a well moisturized soil, at high humidity conditions, the herbicide can be partially solubilized and distributed in the first layers of the soil surface, which will protect it from losses (Deuber, 1992). Afterwards, pre-planting tillage favored that spatial location of the herbicide changed due to a mix of different soil layers $(0-10 \mathrm{~cm})$, providing direct contact between the herbicides and the roots of the transplanted seedlings. The same did not occur when the application was performed at 0 DAT, since after

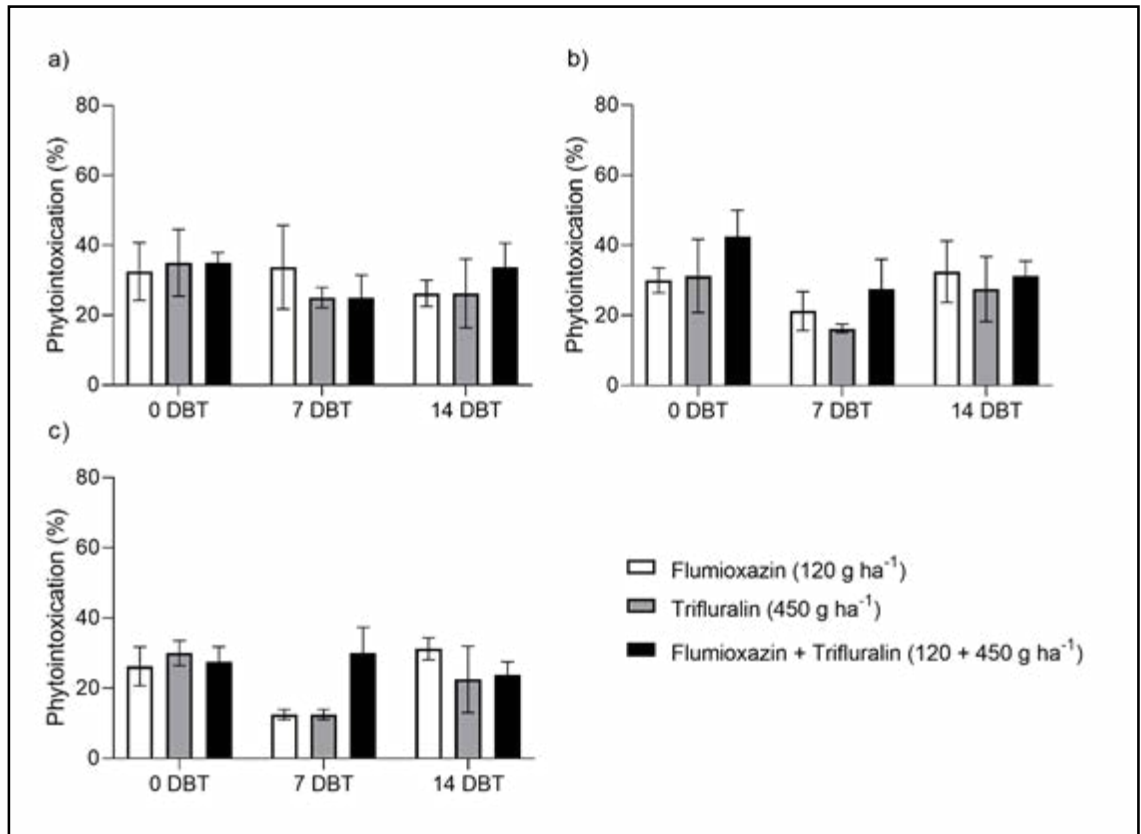

Figure 2. Phytointoxication evaluation of lettuce plants cv. Lucy Brown at 7 (a), 21 (b) and 35 (c) days after transplanting (DDP) in the experiment B (treatments consisted of different herbicide application seasons prior to planting $(15,7$ and 0 DAT) and one soil tillage operation immediately prior to planting the lettuce seedlings). $\mathrm{DBT}=$ days before transplanting. Same lowercase letters do not differ between the herbicide treatments at the same application season and same uppercase letters do not differ between the herbicide treatments between application seasons. Tukey test, 5\% probability. Maringá, UEM, 2016.

Table 1. Results from the harvested experiment after herbicide applications at 14,7 , and 0 days before transplantation (DBT) of lettuce, cultivar Lucy Brown. The soil was tilled before and after the applications. Maringá, UEM, 2016.

\begin{tabular}{|c|c|c|c|c|c|c|c|c|c|}
\hline \multirow{2}{*}{ Treatments } & \multicolumn{3}{|c|}{ Number of leaves } & \multicolumn{3}{|c|}{ Leaf area $\left(\mathrm{cm}^{2}\right)$} & \multicolumn{3}{|c|}{ Lettuce yield $\left(\mathrm{t} \mathrm{ha}^{-1}\right)$} \\
\hline & O DBT* & 7 DBT & 14 DBT & O DBT & 7 DBT & 14 DBT & O DBT & 7 DBT & 14 DBT \\
\hline Flumioxazin & $17.1 \mathrm{bB}$ & $27.0 \mathrm{abA}$ & $22.6 \mathrm{aAB}$ & $21.8 \mathrm{bA}$ & $30.4 \mathrm{abA}$ & $22.0 \mathrm{bA}$ & $19.9 \mathrm{bA}$ & $31.2 \mathrm{abA}$ & $16.8 \mathrm{bA}$ \\
\hline Trifluralin & $28.7 \mathrm{aA}$ & $28.3 \mathrm{aA}$ & $29.5 \mathrm{aA}$ & $56.1 \mathrm{aA}$ & $42.7 \mathrm{aA}$ & $54.6 \mathrm{aA}$ & $47.8 \mathrm{aA}$ & $43.7 \mathrm{aA}$ & $48.4 \mathrm{aA}$ \\
\hline flumioxazin + trifluralin & $17.8 \mathrm{bA}$ & $19.0 \mathrm{bA}$ & $20.8 \mathrm{aA}$ & $16.3 \mathrm{bA}$ & $15.4 \mathrm{bA}$ & $28.2 \mathrm{bA}$ & $23.8 \mathrm{bA}$ & $26.4 \mathrm{bA}$ & $33.3 \mathrm{bA}$ \\
\hline Untreated control & & 31.2 & & & 51.4 & & & 33.2 & \\
\hline $\mathrm{LSD}_{\text {line/column }}$ & 9.92 & 8.99 & 8.99 & 29.07 & 26.33 & 26.33 & 19.40 & 17.5 & 17.5 \\
\hline $\mathrm{LSD}_{\text {dunnet }}$ & & 11.18 & & & 30.7 & & & 21.4 & \\
\hline CV $(\%)$ & & 21.45 & & & 39.23 & & & 37.51 & \\
\hline
\end{tabular}

*Herbicide application season, in days before transplanting (DBT); Same lowercase letters in the column and same uppercase letters in the line do not differ from each other, by Tukey's test at 5\% probability; Averages in bold are significantly lower than the control by the Dunnet test at $5 \%$ probability. $\mathrm{LSD}=$ Least significant diference. 
the herbicide application, the soil was immediately tilled, promoting the herbicide incorporation into deeper layers $(10 \mathrm{~cm})$, preventing direct contact of the herbicide with seedling roots in early development. Leaching and lateral soil movement are restricted and, therefore, trifluralin tends to remain in the soil incorporation zone (Tiryaki et al., 1997).

In the second application season (7 DAT), trifluralin provided higher percentages related to damage to lettuce seedlings transplanted in the evaluation at 7 DDT (50\%) and at 21 DDT (44\%), being the main symptom the reduction of plant size. In the third application season (14 DAT), the initial damages verified were fewer $(35 \%)$ and the plant recovered more abruptly between evaluation seasons (Figure 1c). The results for 14 DAT season showed that the permanence of the product on soil surface for 14 days before incorporation (when seedlings were transplanted), contributed to higher levels of losses by volatilization. The level of persistence of trifluralin in soil is regulated by several factors, including soil moisture, temperature, soil type and duration before incorporation (Messersmith et al., 1971; Horowitz et al., 1974).

Flumioxazin herbicide applied isolated showed phytotoxicity higher than trifluralin herbicide at 7 DDT at all seasons of application $(0,7$ and 14 DAT). This value decreased along the other evaluations (Figure 1). At 21 days after transplanting flumioxazin caused higher percentage of injuries to plants in comparison to the isolated application of trifluralin herbicide treatment when applied in the third season (14 DAT). In the third evaluation (35 DDT), we verified that flumioxazin was the herbicide which showed greater negative effect on the crop in the third application season (14 DAT). Flumioxazin activity may vary according to soil adsorption (Jaremtchuk et al., 2009).

The association of flumioxazin + trifluralin, compared with other treatments, caused greater toxic effect on plants in most evaluations carried out during the crop cycle, showing final phytotoxicity values higher than $35 \%$ in the three application seasons.

The number of leaves per lettuce plant was not affected by the application season considering trifluralin and the flumioxazin + trifluralin mixture. However, the association of flumioxazin + trifluralin reduced the number of leaves per plant when compared with the control in 7 DAT (Table 1). In 0 DAT season, the treatments with isolated flumioxazin and flumioxazin + trifluralin also reduced the number of leaves per plant when compared with the control.

The leaf area of the plants was not affected by the application at different seasons. At all application seasons, flumioxazin and the association of flumioxazin + trifluralin showed lower leaf area of lettuce when compared to the isolated application of trifluralin at 0 and 14 DAT. When compared with the control, the application of the association of flumioxazin + trifluralin decreased the values for this variable at 0 and 7 DAT seasons (Table 1).

The yield of cv. Lucy Brown was not affected by herbicide application season (Table 1). However, within each application season, the authors noticed treatments with reduced crop yield, as for the application of isolated flumioxazin and the association of flumioxazin + trifluralin in relation to the application of trifluralin at 0 and 14 DAT seasons. For application season at 7 DAT, trifluralin herbicide treatment isolated provided higher lettuce yield compare to the association of flumioxazin + trifluralin.

The reduced yield observed with the applications of flumioxazin and flumioxazin + trifluralin comparing with application of isolated trifluralin can be explained by the fact that these treatments caused negative effects on lettuce productivity components (number of leaves and leaf area) when compared with the herbicide-free control.

The action of trifluralin promotes inhibition of cell mitosis, normally acting on meristems and tissues of underground organs such as roots, epicotyls, hypocotyls, plumes, rhizomes, bulbs and seeds (Deuber, 1992). The growing and development of the plants depend on mitosis in meristematic regions, and cell division is a process which requires different cell organelles, structures and products of many genes

Table 2. Results from the harvested experiment after herbicide applications at 14,7 , and 0 days before transplantation of lettuce, cultivar Lucy Brown. The soil was tilled only before the applications. Maringá, UEM, 2016.

\begin{tabular}{|c|c|c|c|c|c|c|c|c|c|}
\hline \multirow{2}{*}{ Treatments } & \multicolumn{3}{|c|}{ Number of leaves } & \multicolumn{3}{|c|}{ Leaf area $\left(\mathrm{cm}^{2}\right)$} & \multicolumn{3}{|c|}{ Lettuce yield $\left(\mathrm{t} \mathrm{ha}^{-1}\right)$} \\
\hline & 0 DBT* & 7 DBT & 14 DBT & O DBT & 7 DBT & 14 DBT & 0 DBT & 7 DBT & 14 DBT \\
\hline Flumioxazin & $27.3 \mathrm{aB}$ & $31.7 \mathrm{aA}$ & $25.6 \mathrm{bB}$ & 38.5 & 53.2 & 39.8 & 35.5 & 38.8 & 35.0 \\
\hline Trifluralin & $27.7 \mathrm{aA}$ & $27.2 \mathrm{bA}$ & $30.3 \mathrm{aA}$ & 47.5 & 40.1 & 48.5 & 42.9 & 36.0 & 39.2 \\
\hline flumioxazin + trifluralin & $25.0 \mathrm{aB}$ & $30.1 \mathrm{abA}$ & $27.5 \mathrm{abAB}$ & 35.0 & 46.8 & 43.3 & 37.8 & 40.5 & 34.6 \\
\hline Untreated control & \multicolumn{3}{|c|}{31.0} & \multicolumn{3}{|c|}{55.8} & \multicolumn{3}{|c|}{44.6} \\
\hline $\mathrm{DMS}_{\text {line/column }}$ & 4.54 & 4.12 & 4.12 & & & & & & \\
\hline $\mathrm{DMS}_{\text {dunnet }}$ & \multicolumn{3}{|c|}{4.9} & & & & & & \\
\hline CV $(\%)$ & \multicolumn{3}{|c|}{8.23} & \multicolumn{3}{|c|}{23.77} & \multicolumn{3}{|c|}{20.23} \\
\hline
\end{tabular}

*Herbicide application season, in days before transplanting (DBT); Same lowercase letters in the column and same uppercase letters in the line do not differ from each other, by Tukey's test at 5\% probability; Averages in bold are significantly lower than the control by the Dunnet test at $5 \%$ probability; LSD $=$ Least significant difference. 
to work properly (Fernandes et al., 2013). The mechanism of action of flumioxazin promotes the inhibition of the enzyme protoporphyrinogen oxidase (PPO) and is characterized by a strong contact effect causing severe lesions on the leaves which may progress to rapid necrosis (Oliveira Junior, 2011). Lipid peroxidation results in rapid loss of membrane integrity and function, bleaching of chloroplast pigments, tissue necrosis, and ultimately inhibition of plant growth and death (Grossmann et al., 2011). Products in this action group are often associated with a rapid onset of symptoms (Mallory-Smith \& Retzinger, 2003).

The combined effects of the two herbicides in relation to the flumioxazin + trifluralin treatment and the isolated application of flumioxazin may be responsible for the negative symptoms in lettuce plants, resulting in higher phytotoxicity levels comparing with the isolated application of trifluralin. Thus, a greater requirement for metabolic expenditure by the plant to promote recovery from injuries caused by these treatments was observed, resulting in lower productivities.

Trifluralin was the most selective treatment, once, when applied isolated, it did not affect lettuce yield or its components at any time of application.

\section{Experiment B}

Significant interaction was observed among factors for number of leaves $(\mathrm{p}<0.05)$. The plants showed low variation in phytotoxicity note scale between treatments (Figure 2), being initially symptoms concerning the reduction in size, observed until the last evaluation (35 DDT), and some necrotic spots on leaves which touched the treated soil, showing recovery afterwards, though.

Treatments based on flumioxazin + trifluralin (applied at 0 DAT season) and flumioxazin (applied at 14 DAT season) resulted in a decrease in number of leaves when compared with the control. Trifluralin isolated caused a negative effect on the number of leaves when applied at 7 DAT and compared to flumioxazin application at the same time (Table 2).

Trifluralin is an herbicide which presents high vapor pressure (Oliveira Junior, 2011a), thus, not being incorporated in experiment $\mathrm{B}$ resulted in a less activity in the soil and consequently greater loss of the product by volatilization. Rodrigues et al. (1998) studied the pre-emergence herbicide trifluralin sprayed on no-tillage system under mulching and irrigated the soil with $20 \mathrm{~mm}$ water after applications; the results showed that trifluralin did not reach the soil and was lost as it was volatilized. These results corroborate the recommendation of incorporating the product to soil. In this experiment even without mulching on soil, the results showed significant losses of trifluralin herbicide through volatilization, due to fewer injuries to lettuce when comparing with the experiment A where the product was incorporated after different seasons on soil surface before seedling planting.

Flumioxazin has a strong contact action, causing the death of sensitive plants when they come into contact with the treated soil layer (Oliveira Junior, 2011). For the soil management conditions of experiment $\mathrm{B}$, the herbicide was restricted to the first soil layers, thus reducing contact with the transplanted lettuce seedlings. Nevertheless, when the leaves eventually touched the soil surface, we observed some necrotic symptoms; these plants recovered until the end of the cycle, though.

Productivity and leaf area of lettuce plants were not influenced by application seasons concerning any evaluated herbicide (Table 2).

In both experiments ( $A$ and $B$ ), the (isolated) trifluralin herbicide application was the treatment which less negatively influenced the analyzed variables, demonstrating its selectivity potential for the lettuce crop.

Thus, observing the results of this study, the authors could conclude that for the conditions of the experiments, lettuce cv. Lucy Brown was insensitive to trifluralin herbicide application at 0,7 and 14 days before seedling transplantation, regardless of the soil management carried out in the area, that is, incorporated or not. Flumioxazin, applied isolated or associated with trifluralin, provided a greater level of toxicity to lettuce plants cv. Lucy Brown.

\section{ACKNOWLEDGEMENTS}

To CAPES for financing this research and to Center for Advanced Studies in Weed Science (NAPD) for supporting the development of the experiments.

\section{REFERENCES}

AGROFIT. Ministério da Agricultura, Pecuária e Abastecimento. 2021. Available at http:// agrofit.agricultura.gov.br/agrofit_cons/ principal agrofit cons. Accessed May 13, 2021

BANZATO, DA; KRONKA, SN. 2015. Experimentação agrícola. Fundação de apoio a pesquisa, ensino e extensão. Jaboticabal, BR: $237 p$.

BERETA, SF; NOHATTO, MA; ROSA, EFF; KASEKER, JF; SANTOS, MC; WITTER, APW. 2021. Seletividade de herbicidas em pós-emergência e controle de plantas daninhas no gergelim. Agrarian 14: 27-35.

CHAUDHARI, S; JEENNINGS, KM; MONKS, DW; JORDAN, DL; GUNTER, CC; LOUWS, FJ. 2015. Response of grafted tomato (Solanun lycopersicum) to herbicides. Weed Technology 29: 800-809.

CHOWDHURY, FI; DORAN, GS; STODART, BJ; CHEN, C; WU, H. 2020. Trifluralin and atrazine sensitivity to selected cereal and legume crops. Agronomy 10: 587-603.

DEUBER, R. Botânica das plantas daninhas. 1992. In: DEUBER, R (ed). Ciências das plantas daninhas. Jaboticabal, BR: FUNEP 431p.

ECHER, R; LOVATTO, PB; TRECHA, CO; SCHIEDECK, G. 2016. Alface à mesa: implicações sócio-econômicas e ambientais da semente ao prato. Revista Thema 13: 17-29.

FENNIMORE, SA; RACHUY, JS; VALDEZ, JA. 2011. Safe lettuce planting intervals following herbicide use on fallow beds. Weed Technology 25: 103-106.

FERNANDES, TCC; PIZANO, MA; MARINMORALES, MA. 2013. Characterization, modes of action and effects of trifluralin: a review. Intech 490-515.

FERREIRA, RLF; NETO, SEA; SILVA, SS; ABUD, EA; REZENDE, MIFL; KUSDRA, JF. 2009. Combinação entre cultivares, ambientes, preparo e cobertura do solo em características agronômicas de alface. Horticultura Brasileira 27: 383-388.

FRANS, RW. 1972. Measuring plant response. In: WILKISON, RE (ed). Research methods in weed science. Melbourne: Southern Weed Science Society. 1: 28-41.

GIANNOPOLITIS, CN; VASSILIOU, G; VIZANTINOPOULOS, S. 1989. Effects of weed interference and herbicides on nitrate and carotene accumulation in lettuce. Journal of Agricultural and Food Chemistry 37: 312-315. 
GIORDANI, GMRC; SANTOS, HS; SCAPIM, CA; CONSTANTIN, J; CALLEGARI, O. 2000. Seletividade de herbicidas aplicados em pré e pós transplante da cultura da alface. Acta Scientiarum 22: 985-991.

GROSSMANN, K; HUTZLER, J; CASPAR, G; KWIATKOWSKI, J; BROMMER, CL. 2011. Saflufenacil (kixor ${ }^{\mathrm{TM}}$ ): Propriedade biocinéticas e mecanismo de seletividade de um novo herbicida inibidor de protoporfitinogênio IX Oxidase. Weed Science 59: 290-298.

HOROWITZ, M; HULIN, N; BLUMENFELD, T. 1974. Behavior and persistence of trifluralin in soil. Weed Research 14: 213-220.

JAREMTCHUK, CC; CONSTANTIN, J; OLIVEIRA JUNIOR, RS; ALONSO, DG; ARANTES, JGZ; BIFFE, DF; ROSO, AC; CAVALIERI, SD. 2009. Efeito residual de flumioxazin sobre a emergência de plantas daninhas em solos de texturas distintas. Planta Daninha 27: 191-196.

MACIEL, CDG; VIDAL, LHI; JADOSKI, SO; IUCHEMIN, CEL; HELVING, EO; SILVA, AAP; DRANCA, AC; INOUE, MH. 2019. Selectivity of herbicides applied in preemergence in chia crop. Revista Brasileira de Ciências Agrárias 14: e5609.
MALLORY-SMITH, CA; RETZINGER, EJ. 2003. Classificação revisada de herbicidas por local de ação para o manejo da resistência de ervas daninhas estratégicas. Weed Technology 17: 605-619.

MESSERSMITH, C; BURNSIDE, O; LAVY, T. 1971. Dissipação biológica e não biológica de trifluralina do solo. Weed Science 19: 285-290.

MONQUERO, PA; BINHA, DP; INÁCIO, EM; SILVA, PV; AMARAL, LR. 2011. Seletividade de herbicidas em variedades de cana-deaçúcar. Bragantia 70: 286-293.

OLIVEIRA JUNIOR, RS. 2011. Mecanismos de ação de herbicidas. In: OLIVEIRA JUNIOR, RS; CONSTANTIN, J; INOUE, MH (eds). Biologia e manejo de plantas daninhas. Curitiba-PR. p.141-192.

OLIVEIRA JUNIOR, RS; INOUE, MH. 2011. Seletividade de herbicidas para culturas e plantas daninhas. In: OLIVEIRA JUNIOR, RS; CONSTANTIN, J; INOUE, MH (eds). Biologia e manejo de plantas daninhas. Curitiba-PR. p.243-262b.

REIS, MR; MELO, CAD; RAPOSO, TP; AQUINO, RFBA; AQUINO, LA. 2017. Selectivity of herbicides to cabagge (Brassica oleracea var. capitata). Planta Daninha 35: e017163938.

RESENDE, FVS; SAMINÊZ, TCO; VIDAL, MC; SOUZA, RB; CLEMENTE, FMV. 2007. Cultivo de alface em sistema orgânico de produção. Embrapa Hortaliças, 16p.

RODRIQUE, BN; LIMA J; YADA, IFU; FORNAROLLF DA. 1998. Influência da cobertura morta no comportamento do herbicida trifluralin. Planta Daninha 16: 163-173.

SALA, FC; COSTA, CP. 2012. Retrospectiva e tendência da alfacicultura brasileira. Horticultura Brasileira 30: 187-194.

SEMINIS VEGETABLE SEEDS. 2016. Catálogo de produtos. Available http://www.seminis. com.br/Produtos/solaris/387>. Accessed October 10, 2016.

TIBURCIO, RAS; FERREIRA, FA; FERREIRA, LR; MACHADO, MS; MACHADO, AFL. 2012. Controle de plantas daninhas e seletividade do flumioxazin para eucalipto. Cerne 18: 523-531.

TIRYAKI, O; GOZEK, K; KHAN SU. 1997. Residues of trifluralin in a soil and their uptake by carrots. Bulletin of Environmental Contamination and Toxicology 59: 58-64. 